\title{
Planctomyces maris sp. nov., nom. rev.
}

\author{
JOHN BAULD† AND JAMES T. STALEY \\ Department of Microbiology and Immunology, School of Medicine, University of Washington, Seattle, \\ Washington 98195
}

The name Planctomyces maris Bauld and Staley 1976 was not included in the recently published Approved Lists of Bacterial Names and hence has no standing in bacteriological nomenclature. However, the name Planctomyces maris sp. nov. is herein revived for the same organism with which it was originally associated and, by this action, now has valid status. The type strain of P. maris is strain 53430 (= ATCC 29201)

The bacterial name Planctomyces maris was validly published by Bauld and Staley (1) before 1 January 1980 , but it became invalid by not having been announced in the International Journal of Systematic Bacteriology in accord with Rule 27 of the Bacteriological Code (2). Therefore, $P$. maris was not included in the recently published Approved Lists of Bacterial Names (3). The purpose of this communication is to effect the revival of this name for the same organism with which it was originally associated and thereby give it valid status. The type strain

\footnotetext{
$\dagger$ Present address: Baas Becking Geobiological Laboratory, Canberra City ACT, Australia 2601.
}

of Planctomyces maris sp. nov., nom. rev. is strain 534-30 (= ATCC 29201). The descriptions of the species and the type strain have been previously published (1).

\section{LITERATURE CITED}

1. Bauld, J., and J. T. Staley. 1976. Planctomyces maris sp. nov.: a marine isolate of the Planctomyces-Blastocaulis group of budding bacteria. J. Gen. Microbiol. 97: 45-55.

2. Lapage, S. P., P. H. A. Sneath, E. F. Lessel, V. B. D. Skerman, H. P. R. Seeliger, and W. A. Clark. 1975. International code of nomenclature of bacteria. American Society for Microbiology, Washington, D. C.

3. Skerman, V. B. D., V. McGowan, and P. H. A. Sneath (ed.). 1980. Approved lists of bacterial names. Int. J. Syst. Bacteriol. 30:225-420. 